ISBN 978-81-933894-1-6 2017 International Conference on Arts, Social Sciences, History and Interdisciplinary Studies

(ASSHIS'2017)

Kyoto (Japan), April. 20-21,2017

\title{
Poverty and Child Marriage in Sambas West Kalimantan: Malay Girls Marriage in Sungai Kumpai Village
}

\begin{abstract}
Atem
Sociology Department, Political and Social Science Faculty Padjadjaran University

Abstract: This paper attemp to investigate about the child marriage in rural area who is mainly inhabited by Malay ethnic. This study took about Malay girls marriage in Sungai Kumpai Village West Kalimantan. Child marriage has garnered significant global attention in the last decade in response to growing evidence on the scale and scope of the problem. Indonesia entered to top ten contries in ASEAN which highest child marriage rates. The prevalence of child marriage have spread in to many areas, one of them is Sambas district in West Kalimantan. Marriage in Malay is a phase of life that sacred value, particularly in Sambas. The wedding procession was made in detail and netly arranged in belonging with tradition and customs. The reality of child marriage was happend in many case and have ruined the future of children, particularly related to poverty issues and their household sustainability. This practice is not only ignored the fundamental rights of the children but also took refuge under the customs religion. The child marriage in Sambas Malay society was occured in long time ago, and now was changed just of the married decision motives. This paper aim to examine and describe the child marriage and poverty which took place of the Malay society in Sambas West Kalimantan especially in Sungai Kumpai Village through literature review and observation techiques.
\end{abstract}

Keyword: Child Marriage, Poverty, Girls, Malay

\section{Introduction}

One of the issues is concerned by the world about children is the child marriage. Child marriage, defined by the UNICEF ${ }^{[1]}$ as marriage prior to age 18 years, is a pervasive human rights violation disproportionately affecting South Asia as a whole (UNICEF, 2009). 21/3 girls in the world marry before they are eighteen, and 1 of 9 girls marry before fifteen (Asmarita. 2015) ${ }^{[2]}$. The world eyes on Indonesia about child protection and child right. The United Nations, through UNICEF, underlines the issue of child marriage rapidly occurs in Indonesia, especially in a village. Based on Council of Foreign Relations data, Indonesia includes 10 countries in the world with the high rate of child marriage, and place Indonesia in the second place after Cambodia in ASEAN (Candraningrum, 2016) ${ }^{[3]}$.

The highest rate of child marriage spread in all over regions, it describes that Indonesia is alert of child marriage. The same thing goes in West Kalimantan, the prevalence rate of child marriage has increased. In 2002, the rate of child marriage was about 9,3\% and then it increased 22,9\% in 2012 and the last data is about $29,9 \%$ which spreads especially in the village (Ramadhan, 2014) ${ }^{[4]}$. Generally, the child marriage affects children live in the long term especially girl, and it will cause other problems 
in all aspects such as health, education and socioeconomic. The main issue relates to poverty on children. The poverty that occurs in the family will assemble their children vulnerable for marriage.

World Bank Institute (2002) defines a vulnerable as an opportunity or a risk to be poor or even being poorer in the future. It cannot be denied that poverty is the push factor for the family to marry their daughters who are considered to cut down the burden. When the child marriage occurs rapidly, it will lead to human trafficking, forced labor, family violence, psychology impact, and poverty.

For Malay in Sambas regency at Sungai Kumpai village, the phenomenon of child marriage is common to happen. Child marriage is no longer taboo for them but, Malays in Sungai Kumpai village get used to deal with child marriage before the girls are about eighteen. It relates to socioeconomic condition particular when the poverty shapes the wall that cannot be bridged. The poverty is the trigger for child marriage and the risk of poverty on the girl.

The phenomenon of child marriage in Sambas Malays society is such the iceberg phenomenon where the cases are only a few recorded than the actual cases. For people of Sungai Kumpai village, the child marriage is the challenge because it occurs increasingly and still no way out comprehensively to overcome this issue. Therefore, the study about child marriage is very important due to it is getting complex and bringing the effect on the lives of children for the long term.

\section{Research Methodology}

This study uses the qualitative approach with the technique of observation and literature study. The data of this article is secondary data, which is obtained from various sources such as books, journals, proceedings, online news and online literature. The rate of this cases is received directly from the local agency of Sambas regency. Data analysis is explained descriptively through discourse concept and secondary data that have been obtained before.

The study took place in Sambas regency and the phenomenon is focused at Sungai Kumpai village, the study is decided purposively, with considering that the location is the area with the highest Malay ethnics in West Borneo and the socioeconomic condition is lower also with the higher child marriage case.

\section{Results and Discussion}

\subsection{The Reality of Child Marriage in Sambas}

Sambas is one of regency located on West Borneo Island and border to East Malaysia. There is two districts border overland to Malaysia which is Paloh and Sajingan Besar districts. Sambas regency lacks quality human resources if it is compared to another area in West Borneo, it can be detected from the low of Human Development Index (HDI). Based on Statistics Indonesia in the regency level in West Kalimantan around 2009-2010, showed that Sambas had the lowest HDI which was 64,46 in 2009 and 64,84 in 2010, then it increased in 2011-2013 but it reduced again about 64,14 in 2014 and $2015[5]$.

Sambas regency is multiethnic area but, the majority of Sambas is lived by Malays. The term of Malay according to Alqadrie is that Malay refers to identification media than as an ethnic group which means a primordialism (Bahari, 2008) [6]. Malays are identified as Muslims because of common sense which says that whoever converts to Islam means that he/she is Malay and so are people of Sambas. This common sense has been part of the way of think in Sambas regency. Fatmawati reveals that the term of Malay has shown that Malay ethnic consider themselves as Malay who are united and bounded by Malay tradition such as being a Muslim, speak Malay and apply the custom of Malay and also the moral spiritual of Malay is Islamic spirit (Bahari, 2008) [7].

Marriage for Sambas Malay is the most important thing and has sacred meaning because it reflects value and culture that contains norm and custom, therefore, it will be celebrated with full of joy. The local government of Sambas regency has been concerned about Child marriage issue because the impact of child marriage produces development issue, poverty, prosperously and social problem in Sambas. Generally, the poverty level in Sambas regency is quite high, based on Regional Development Planning Agency (BAPPEDA) of Sambas regency, the poverty level in 2015 was about 9,42\% or 
383.700 people (Karsuwadi, 2016).[8] Based on Women Empowerment Child Protection And Family Planning of Sambas regency, child marriage case was quite high about 25,51\% in 2013 from total 5.115 marriages and the divorce was about 815 cases, while in 2014 child marriage case was about $26,39 \%$ from total 4.138 marriages with 771 divorce cases. [9] Here it is, the spreading case of child marriage occurs in every district of Sambas regency.

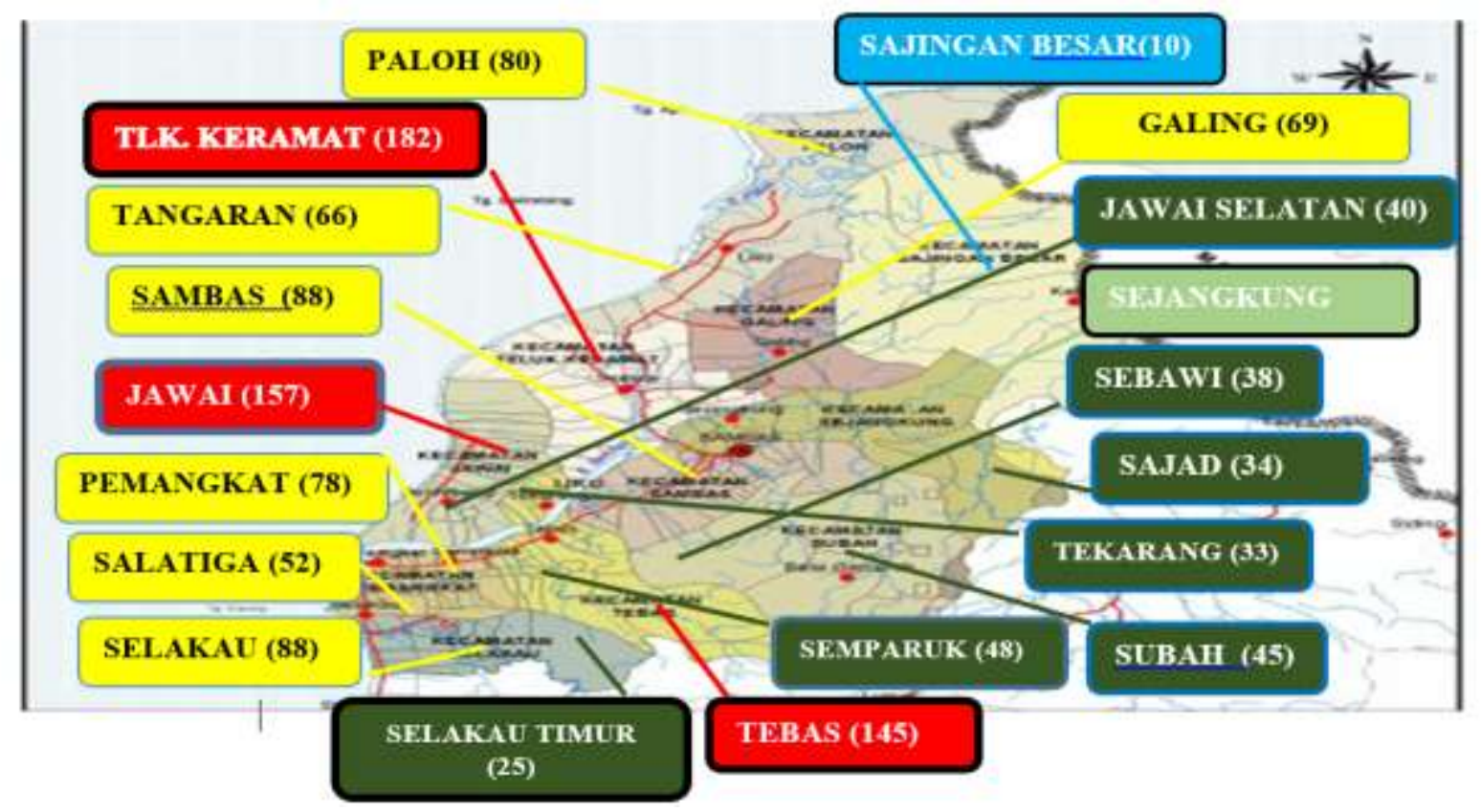

Figure 1 : Total of Child Marriage in Sambas Regency (Per Sub district) in 2014.

Source: Based on Women Empowerment Child Protection And Family Planning of Sambas Regency

\subsection{The Phenomenon in Sungai Kumpai village}

More than 99,4\% people in Sungai Kumpai are Malay ethnics, based on previous explanation about the term of "Malay" means that more than $90 \%$ people of Sungai Kumpai village are also Muslims. Based on observation, the phenomenon of child marriage in Sungai Kumpai village rapidly occurs. Many studies about child marriage which relates this case to Islam ideology. According to Engelchin, And Massry (2016) Although Islam has given women the right to decide who to marry, it has not set a minimum age to marry ${ }^{90]}$. The researcher categorizes child marriage that happens in Sungai Kumpai village into two groups. First, child marriage happens to child labor and child drop out of school; second, child marriage happens to the child who is at school age. Most children in Sungai Kumpai village who drop out of school will decide to work in outside village and tend to work in Malaysia. In Malaysia, they work as a maid or waitress while the boys work as a labor in palm farm or construction worker.

Children who drop out of school are the risk to marry at the young age than those who are still in school because they are the no longer burden to their parents or family and can take self-responsible. Ngoyen and Wodon (2014) argue that Girl with the lower education prospect may be willing to marry early or their parent may be more inclined to let them marry early ${ }^{[11]}$. Most child marriage occurs due to pregnancy, 7 of 10 children in Sungai Kumpai village marry young (married by accident). Those who have worked deciding to marry not because of pregnancy but they can take responsible for themselves. Marriage is decided by personal demand, not like those who marry during school time, they are forced to marry because of pregnancy and considered as a disgrace to the family and that is why married is the best solution.

Child marriage that happens because of pregnancy, in people of Sungai Kumpai village leads to social construction which generates them to accept this phenomenon as a usual thing. Married is the only solution for those who are pregnant before getting married. Actually, most parents in Sungai 
Kumpai no longer force their children for child marriage but, pregnancy before married frequently makes them approve child marriage. Child marriage is not always registered legally based on state law but legally based on religion law or nikah siri (unregistered marriage). According to Pamuji ${ }^{[11]}$ in unregistered marriage, the women and her children will susceptible to have a risk of neglect by the husband, therefore, their life necessities and financial need will susceptible do not to fulfilled ${ }^{[12]}$.

\subsection{The Poverty and Impoverishment of Girls}

Poverty is a complexity phenomenon and cannot be defined from a point of view. It can be detected from fulfilling basic needs for self-development for the better life, the basic needs that are meant such as food, health, education, job opportunity etc. Poverty from gender aspect is identified by World Bank (2003) into 4 dimensions which are, Women's lack of empowerment, opportunity, capacity and security ${ }^{[13]}$. United Nations Population Fund (UNFPA) found that in 2012 child marriage mostly occurred to the child who was uneducated, living below the standard of life in the village (Candraningrum, Dhewy, and Pratiwi, 2016) ${ }^{[14]}$. The people of Sungai Kumpai village are categorized as the poor society. Based on data of Sungai Kumpai profile in 2016 viewed from people's livelihood, the majority people work as a farmer or labor with inconsistent payment. In the context of people income, the majority people of Sungai Kumpai village are not stabilized when it comes to income.

Child marriage that occurs in Sungai Kumpai village cannot be separated from poverty. Many children who are still productive age, uneducated or unable to continue their study after graduating from elementary school or junior high school. The common issue relates to this situation is a family cost or a decision to help the family immediately for economic collapse. While the child who marries during their school time will cast to stop schooling and becoming the housewife in the early age. Many studies have explained the terrible impact of child marriage especially on girls which are impoverishment. The girls is the main object and harmed during child marriage. The result of observation on people of Sungai Kumpai village, tells us that child marriage is the impact of poverty and also as impoverishment woman.

The girls who come from the poor family have no chance to access the higher education and it causes them to marry in the early age while those who marry during school time will not continue their study. The common perception of parents in Indonesia that the daughter is considered as a burden while the son is an asset (Anshor, 2016) ${ }^{[15]}$. It generates another issue relating to human resource. The uneducated child is unable to compete for a better job. It invents them to be a child labor. Generally, they do not continue their study and choose to work illegally in Malaysia. The work environment is far away from parent's attention will set them free for interaction with other workers especially the man so that the interaction will lead them to marriage. If it happens, the purpose of the girls to help the family economy fails because they have to mind their own family. After married, they return to the village or even stick with their parents while the husband will be busy for working. This condition strengthened the evil circle of poverty in the family, a chance of achieving productive resource for girls will be reducing because they have to take care their own family and the only income is expected by them is from their husband.

The girls married is not only playing the role as a housewife but also work as a farmer, this is not a payment job due to the farming is only enough for a mode of consumption not for the mode of production. To collect financial source, the girls are involved in helping their parents in rubber tapping or working for somebody else as a rubber tapper but it cannot sustain the needs of a family, neither can their husband. This condition will form the poor family over and over again. The direct impact of poverty is felt by the woman (in this case are the girls) because the woman is involved in taking care the family especially for providing the foods and children needs and family needs while their husband is not always at home. Another risk for the girls married in Sungai Kumpai village is the divorce. Immature or unready for settling down affects the family's harmony and intimacy and leads to divorce. The divorce will be a loss to the girls because they have to head the family, moreover when the 
marriage is only a short time. The girls or women who are divorced in Sungai Kumpai village will extract to work as Indonesian Migrant Worker in Malaysia, they daycares their children to their parents. This condition is getting extended the poverty.

\section{Conclusion}

Poverty is a multidimensional phenomenon which is able to lead to bad condition on every single person including poor group. The child marriage becomes one of the terrible impacts of poverty when it is viewed from the gender perspective will produce horrible life for the woman. Many risks are caused by child marriage particularly on girls, which are the education issue, job opportunity, reproductive health, and divorce. There are some important points from the phenomenon of child marriage in Sungai Kumpai village, first, child marriage happens to poor family but it is not the result of forced marriage; second, the most factor of child marriage in Sungai Kumpai village because of married by accident; third, child marriage happens whether to children who are the school age or not; fourth, the child marriage invents child labour.

\section{Acknowledgements}

Thanks to everyone who helped in the preparation of this paper and also thanks to LPDP (Indonesia Endowment Fund for Educationn) which gave scholarships to me and as sponsorship of me to join this international conference.

\section{References}

[1] A.R.C Gomez, and J. G Sikverman. (2014). Multisectorial Afghan Perspectives On Girl Child Marriage: Foundations For Change Do Exist In Afghanistan. Violence Against Women. 20 (12). pp.1489-1505. https://doi.org/10.1177/1077801211403288

[2] Asmarita. (2015). Peran Unicef Dalam Menangani Kasus Pernikahan Anak di Bawah Umur Di India. Jurnal JOM FISIP. 2 (2). pp.1-15.

[3] D. Candraningrum. (2016). Pernikahan Anak: Status Anak Perempuan. Jurnal Perempuan. 21 (1). pp.4-7.

[4] J. A. Ramadhan. (2014). Pernikahan Dini Di Kalbar Tinggi 229 ABG Sudah Melahirkan. Retrieved Desember 152016 from https://Www.Merdeka.Com/Peristiwa/Pernikahan-Dini-Di-Kalbar-Tinggi-229-Abg-Sudah-Melahirkan.html.

[5] Badan Pusat Statistik Provinsi Kalimantan Barat. "Indeks Pembangunan Manusia Provinsi kalbar dan Kabupaten/kota 1996-2015.” Retrieved January 202017 from https://kalbar.bps.go.id/linkTabelStatis/view/id/55

[6] Y. Bahari. (2008). Model Komunikasi Lintas Budaya Dalam Resolusi Konflik Berbasis Pranata Adat Melayu Dan Madura Di Kalimantan. Jurnal Ilmu Komunikasi. 6 (2). pp.1-12.

[7] Y. Bahari. (2008). Model Komunikasi Lintas Budaya Dalam Resolusi Konflik Berbasis Pranata Adat Melayu Dan Madura Di Kalimantan. Jurnal Ilmu Komunikasi. 6 (2). pp.1-12.

[8] R. Karsuwadi. (2016). Tribun Pontianak. Bappeda: Tingkat Kemiskinan di Sambas 9,42 persen. Retrieved February 15 2017 from http://pontianak.tribunnews.com/2016/12/22/bappeda-tingkat-kemiskinan-di-sambas-942-persen

[9] Data Jumlah Pernikahan Dini Tahun 2014. Badan Pemberdayaan Perempuan, Perlindungan Anak dan Keluarga Berencana Kabupaten Sambas.

[10] Engelchin, D. S, Huss, E, and Massry, N. (2016). The Experience of Early Marriage: Perspectives of Engaged and Married Muslim Women In Israel. Journal of Adolescent Research. 31 (6). pp. 725-749 https://doi.org/10.1177/0743558415605167

[11] M.C. Ngoyen, Q. Wodon and World Bank (2014) Impact of Chil Marriage an Literacy And Educatioan Attainment In Africa. Paper Prepaered for Atask Funded By the Global Partnership for Education.

[12] W. S. Pamuji. (2016). Status Anak Dan Perempuan Dalam Perkawinan Siri. Jurnal Perempuan. 21 (1), pp.96-115.

[13] Indraswari. (2009). Perempuan dan kemiskinan. Jurnal Analisis Sosial. 14 (2), pp. 40-52.

[14] D. Candraningrum, A.Dhewy, and Andi, M.P. (2016). Takut Zina, Pendidikan Rendah, dan Kemiskinan: Status Anak Perempuan dalam Pernikahan Anak di Sukabumi Jawa Barat. Jurnal Perempuan. 21 (1), pp.149-184.

[15] Anshor, M.U. (2016). Kerentanan Anak Perempuan dalam Pernikahan Anak. Jurnal Perempuan. 21 (1), pp. 116-129. 